\title{
Monophasic action potentials of right atrium and electrophysiological properties of AV conducting system in patients with hypothyroidism
}

\author{
S. Gavrilescu, C. Luca, C. Streian, G. Lungu, and G. Deutsch \\ From the Department of Internal Medicine and Cardiology, Institute of Medicine, Timisoara, Rumania
}

In 12 patients with manifest hypothyroidism right atrial monophasic action potentials showed a significant prolongation in comparison with data from normal or euthyroid patients. Atrial effective refractory periods were also significantly prolonged. After thyroid treatment the monophasic action potential duration and the effective refractory period of the right atrium were within normal ranges.

In 6 hypothyroid patients studies of $A V$ conduction with the aid of His bundle electrography and atrial pacing showed a supraHisian conduction delay which was manifest in one case and latent in another two. InfraHisian conduction delay was encountered in 2 cases.

Experimental studies have shown significant effects of the thyroid hormone on atrial muscle: a shortening of the repolarization phase of the action potential (Freedberg, Papp, and Vaughan Williams, 1970; Vaughan Williams, 1970), a shortening of the effective refractory period, and a reduction in the diastolic stimulation threshold as compared to euthyroid atria (Arnsdorf and Childers, 1970). An increased rate of diastolic depolarization in the sinoatrial node from thyrotoxic atria has also recently been shown (Johnson, Freedberg, and Marshall, 1973). Hypothyroidism had the opposite effects.

Only limited data exist concerning electrophysiological properties of the AV conduction system during hypothyroidism. The PR interval is usually normal in hypothyroidism though occasionally it may be prolonged (Bellet, 1971). Delayed AV conduction or complete $\mathrm{AV}$ block have been also reported (Ibrahim, 1957).

With the introduction of monophasic action potential (MAP) recording (Olsson, 1971; Brorson, 1975), a method has become available for the study of de- and repolarization phenomena in the cardiac muscle in situ, the results of which can be compared with data from studies with intracellular electrodes (Hoffman et al., 1959).

In this paper we report our findings in patients with hypothyroidism in whom electrophysiological properties of the right atrium were investigated Received 27 April 1976. with the aid of MAP recordings. In addition, atrial pacing and His bundle electrograms were used to study the AV conduction system.

\section{Subjects and methods}

Twelve patients, 9 women and 3 men, aged between 35 and 54 years, were studied. All had clinical signs of hypothyroidism and low values of the total serum thyroxine (Seligson and Seligson, 1972). All maintained normal sinus rhythm and were without heart failure. None of them was under treatment with cardioactive drugs and no premedication was given before the investigation. After informed consent, MAP recordings were obtained with a bipolar suction electrode catheter passed percutaneously to the right chambers of the heart using a previously described technique (Gavrilescu et al., 1972a, b). A bipolar pacing electrode was introduced via the brachial or femoral vein into the right atrium. A specially constructed battery-powered pulse generator was used to pace the atrium and for testing the refractoriness of the atrial tissue with the extrastimulus method (Wit et al., 1970). The basic pacing cycle was $700 \mathrm{~ms}$, and extrastimuli with a strength twice that of the diastolic threshold were delivered after each eighth beat. The Fig. shows an example of the determination of the atrial effective refractory period (AERP). MAP recordings were obtained from the mid right 

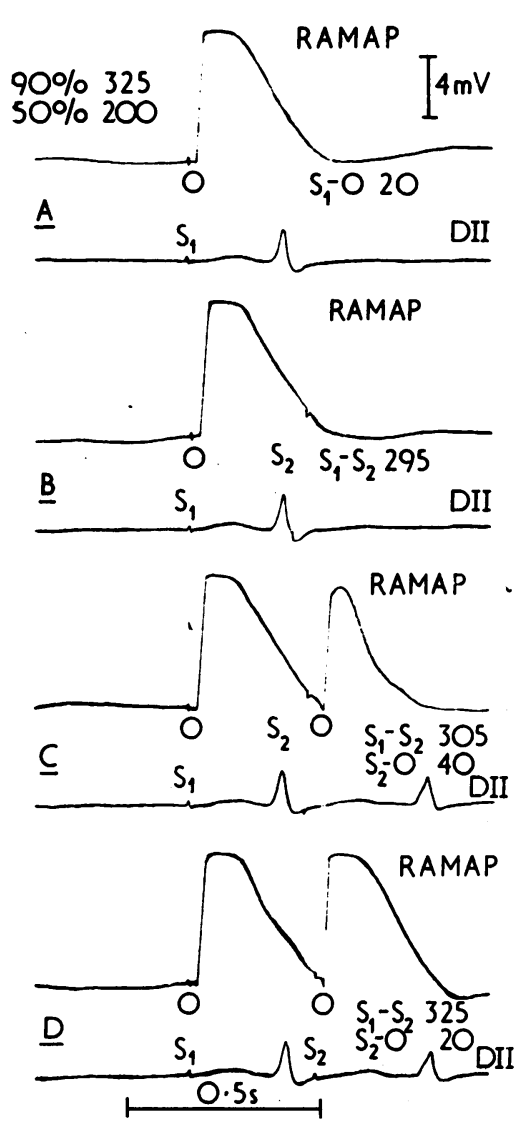

FIG. Case 4 (Table 1). Right atrial monophasic action potential recording (RAMAP) showing the determination of the effective refractory period of the atrium. $S_{1}$ driving stimulus; $S_{2}$, testing stimulus. In $B, S_{1}-S_{2}$ of 295 ms represents the longest interval in which $S_{2}$ is not followed by an atrial response (AERP). (C) shows the atrial response during relative refractory period, and (D) shows the full recovery of atrial excitability.

atrium in order to avoid variations caused by the position of the electrode. At least $10 \mathrm{MAP}$ complexes were measured and the mean values determined. The MAP complexes were analysed according to Olsson (1971) and Brorson (1975). The MAP duration was measured at 90 per cent and 50 per cent repolarization, and from these values a measure of the relative repolarization rate during phase 3 (RRR ph 3) was calculated and expressed in per cent/s (Olsson, 1971).

Atrial MAPs were acceptable if the amplitude exceeded $8 \mathrm{mV}$, the course of the repolarization was smooth and was not distorted by the QRS deflec- tion, and was stable for at least 20 seconds. The accuracy of the measured intervals was within $5 \mathrm{~ms}$. This was determined by repeated measurements made by the same observer, and by independent measurements made by different observers.

In 7 patients the recordings were repeated after 3 to 4 weeks of thyroid treatment. In 6 patients in addition to MAP studies, His bundle electrograms were recorded using a tripolar electrode, introduced via the right femoral vein (Scherlag et al., 1969). The conduction intervals were measured during sinus rhythm and during atrial pacing up to rates of 160 beats per minute.

The values obtained in hypothyroid patients were compared with MAP recordings and AERP determinations obtained in a similar manner in 12 normal subjects, with normal total serum thyroxine values, aged between 32 and 55 years.

\section{Results}

Table 1 shows the results of the MAP recordings in the hypothyroid patients before and after thyroid treatment. Table 2 shows the data from the normal group. The hypothyroid state is associated with a significant lengthening $(P<0.05)$ of MAP duration at 90 per cent and 50 per cent repolarization and of the AERP in comparison with the normal group or hypothyroid treated patients. There are no significant differences between the control group and hypothyroid patients after thyroid treatment. Atrial RRR ph 3 showed no significant differences in the three groups studied.

Table 3 shows the results of the His bundle recordings. AV conduction was normal in sinus rhythm in 3 of the 6 studied patients. One patient (Case 11, Table 1) had first degree AV block at the supraHisian level, while 2 patients (Cases 1 and 6 , Table 1) had $\mathrm{HV}$ interval prolongation. With atrial pacing $\mathrm{AH}$ interval increased progressively in 3 patients (Cases 6, 9, and 11, Table 1), Wenckebach periods occurred at a rate of 150 and 110 per minute, while in the other 3 patients $1: 1 \mathrm{AV}$ conduction took place up to a heart rate of 160 per minute. These changes suggest a latent conduction disturbance in the atrionodal area in Cases 6 and 9.

\section{Discussion}

In a former paper from our laboratory (Cotoi et al., 1972a) a lengthening of right atrial MAP in patients with myxoedema and a significant shortening after thyroid treatment was noted. However, there were also important variations in heart rate which was slow in patients with hypothyroidism and faster 
TABLE 1 Paced right atrial monophasic action potential (RAMAP) recordings in 12 patients with hypothyroidism (cycle length $700 \mathrm{~ms}$ ) before and after thyroid treatment.

\begin{tabular}{|c|c|c|c|c|c|c|c|c|c|c|c|}
\hline \multirow{3}{*}{$\begin{array}{l}\text { Case } \\
\text { No. }\end{array}$} & \multirow{3}{*}{$\begin{array}{l}\text { Age } \\
(y) \\
\text { and } \\
\text { sex }\end{array}$} & \multicolumn{6}{|c|}{ Before thyroid treatment } & \multicolumn{4}{|c|}{ After thyroid treatment } \\
\hline & & \multirow{2}{*}{$\begin{array}{l}\text { Total serum } \\
\text { thyroxine } \\
\text { ( } \mathrm{gg} / 100 \\
\mathrm{ml})\end{array}$} & \multicolumn{2}{|c|}{$R A M A P$ duration } & \multirow{2}{*}{$\begin{array}{l}\text { RARRR } \\
\text { ph } 3 \\
\% / s\end{array}$} & \multirow{2}{*}{$\begin{array}{c}A E R P \\
(m s)\end{array}$} & \multirow{2}{*}{$\begin{array}{l}\text { Total serum } \\
\text { thyroxine } \\
(\mu \mathrm{g} / 100 \mathrm{ml})\end{array}$} & \multicolumn{2}{|c|}{$R A M A P$ duration } & \multirow{2}{*}{$\begin{array}{l}\text { RARRR } \\
\text { ph } 3 \\
(\% / s)\end{array}$} & \multirow{2}{*}{$\begin{array}{c}\text { AERP } \\
\text { (ms) }\end{array}$} \\
\hline & & & $\begin{array}{l}90 \% \text { Re- } \\
\text { polarization } \\
\text { (ms) }\end{array}$ & $\begin{array}{l}50 \% \text { Re- } \\
\text { polarization } \\
\text { (ms) }\end{array}$ & & & & $\begin{array}{l}90 \% \text { Re- } \\
\text { polarization } \\
\text { (ms) }\end{array}$ & $\begin{array}{l}50 \% \text { Re- } \\
\text { polarization } \\
\text { (ms) }\end{array}$ & & \\
\hline 1 & $37 \mathrm{~F}$ & 0.50 & 335 & 270 & 615 & 310 & $5 \cdot 27$ & 266 & 158 & $370 \cdot 37$ & 243 \\
\hline 2 & $44 \mathrm{~F}$ & $0 \cdot 47$ & 270 & 200 & 533 & 240 & - & - & - & & - \\
\hline 3 & $36 \mathrm{~F}$ & 0.43 & 300 & 174 & 317 & 280 & 4.93 & 252 & 164 & $454 \cdot 55$ & 235 \\
\hline 4 & $35 \mathrm{~F}$ & 2.89 & 325 & 200 & 533 & 295 & $6 \cdot 87$ & 258 & 160 & $408 \cdot 16$ & 230 \\
\hline 5 & $42 \mathrm{M}$ & 3.43 & 280 & 200 & 500 & 270 & - & 一 & 一 & 一 & - \\
\hline 6 & $40 \mathrm{~F}$ & $2 \cdot 27$ & 245 & 150 & 421 & 225 & 5.03 & 240 & 140 & 400.00 & 220 \\
\hline 7 & $53 \mathrm{M}$ & $3 \cdot 15$ & 315 & 206 & 367 & 290 & 4.97 & 260 & 150 & 363.64 & 240 \\
\hline 8 & $50 \mathrm{~F}$ & 0.29 & 280 & 180 & 400 & 270 & 二 & - & - & & - \\
\hline 9 & $47 \mathrm{~F}$ & 0.32 & 300 & 230 & 571 & 275 & $4 \cdot 11$ & 255 & 160 & 421.05 & 238 \\
\hline 10 & $49 \mathrm{~F}$ & $3 \cdot 36$ & 280 & 198 & 488 & 260 & $4 \cdot 75$ & 250 & 153 & $412 \cdot 37$ & 232 \\
\hline 11 & $54 \mathrm{M}$ & 0.40 & 285 & 210 & 533 & 260 & - & - & - & - & - \\
\hline 12 & $46 \mathrm{~F}$ & $0 \cdot 27$ & 294 & 176 & 347 & 265 & - & - & - & 一 & - \\
\hline \multirow{6}{*}{\multicolumn{2}{|c|}{$\begin{array}{l}\text { Mean } \\
\text { SD } \\
\text { SE } \\
\text { No. } \\
\text { Significance } \\
\quad \text { at }\end{array}$}} & $1 \cdot 78$ & $292 \cdot 4$ & 199.5 & $468 \cdot 8$ & $270 \cdot 0$ & $5 \cdot 13$ & $254 \cdot 4$ & 155.0 & $404 \cdot 3$ & $234 \cdot 0$ \\
\hline & & 0.52 & $7 \cdot 8$ & $9 \cdot 3$ & 30.0 & $7 \cdot 3$ & 0.52 & $7 \cdot 8$ & $9 \cdot 3$ & $30 \cdot 0$ & $7 \cdot 3$ \\
\hline & & 0.41 & $7 \cdot 2$ & $8 \cdot 7$ & $27 \cdot 6$ & $6 \cdot 7$ & 0.32 & $3 \cdot 1$ & $3 \cdot 0$ & $11 \cdot 7$ & $2.9^{\prime \prime}$ \\
\hline & & 12 & 12 & 12 & 12 & 12 & 7 & 7 & 7 & 7 & 7 \\
\hline & & & & & & & & & & & \\
\hline & & $\begin{array}{l}0.05 \\
\mathrm{~S}\end{array}$ & $\mathbf{S}$ & $\mathbf{S}$ & NS & $\mathbf{S}$ & & $S$ & $\mathbf{S}$ & NS & S \\
\hline
\end{tabular}

Conversion factor from Traditional to SI Units: Thyroxine: $1 \mu \mathrm{g} / 100 \mathrm{ml} \approx 78.8 \mathrm{mmol} / 1$.

RARRR = Right atrial relative repolarization rate: $A E R P=$ Atrial effective refractory period.

TABLE 2 Paced right atrial MAP recordings in 12 normal subjects (cycle length $700 \mathrm{~ms}$ )

\begin{tabular}{|c|c|c|c|c|c|c|c|}
\hline \multirow{2}{*}{$\begin{array}{l}\text { Case } \\
\text { No. }\end{array}$} & \multirow[t]{2}{*}{ Age (y) } & \multirow[t]{2}{*}{ Sex } & \multirow{2}{*}{$\begin{array}{l}\text { Total serum } \\
\text { thyroxine }(\mu \mathrm{g} / 100 \mathrm{ml})\end{array}$} & \multicolumn{2}{|l|}{$R A M A P$ duration } & \multirow[t]{2}{*}{ RARRR ph $3(\% / s)$} & \multirow[t]{2}{*}{$A E R P$ (ms) } \\
\hline & & & & $\begin{array}{l}90 \% \text { Repolarization } \\
\text { (ms) }\end{array}$ & $\begin{array}{l}50 \% \text { Repolarization } \\
\text { (ms) }\end{array}$ & & \\
\hline $\begin{array}{r}1 \\
2 \\
3 \\
4 \\
5 \\
6 \\
7 \\
8 \\
9 \\
10 \\
11 \\
12\end{array}$ & $\begin{array}{l}46 \\
32 \\
37 \\
41 \\
43 \\
47 \\
51 \\
54 \\
35 \\
48 \\
55 \\
50\end{array}$ & $\begin{array}{l}\mathbf{F} \\
\mathbf{M} \\
\mathbf{M} \\
\mathrm{F} \\
\mathbf{F} \\
\mathbf{M} \\
\mathbf{F} \\
\mathbf{M} \\
\mathbf{F} \\
\mathbf{F} \\
\mathbf{F} \\
\mathbf{M}\end{array}$ & $\begin{array}{l}6.3 \\
5 \cdot 8 \\
7 \cdot 6 \\
8 \cdot 0 \\
6.9 \\
7 \cdot 9 \\
8 \cdot 5 \\
5 \cdot 7 \\
5.9 \\
8 \cdot 8 \\
8.4 \\
6.9\end{array}$ & $\begin{array}{l}255 \\
226 \\
270 \\
276 \\
245 \\
237 \\
263 \\
232 \\
240 \\
266 \\
270 \\
228\end{array}$ & $\begin{array}{l}167 \\
132 \\
158 \\
165 \\
150 \\
143 \\
153 \\
140 \\
138 \\
160 \\
165 \\
135\end{array}$ & $\begin{array}{l}454 \cdot 55 \\
425 \cdot 53 \\
357 \cdot 14 \\
360 \cdot 36 \\
421 \cdot 05 \\
425 \cdot 53 \\
363 \cdot 64 \\
434 \cdot 78 \\
392 \cdot 16 \\
377 \cdot 36 \\
380 \cdot 95 \\
430 \cdot 11\end{array}$ & $\begin{array}{l}240 \\
230 \\
255 \\
260 \\
235 \\
225 \\
253 \\
227 \\
230 \\
248 \\
256 \\
225\end{array}$ \\
\hline $\begin{array}{l}\text { Mean } \\
\text { SD } \\
\text { SE } \\
\text { No. }\end{array}$ & & & $\begin{array}{l}7 \cdot 2 \\
0.68 \\
0 \cdot 23 \\
12\end{array}$ & $\begin{array}{r}250 \cdot 7 \\
7 \cdot 2 \\
4 \cdot 3 \\
12\end{array}$ & $\begin{array}{r}155 \cdot 0 \\
8 \cdot 7 \\
3 \cdot 7 \\
12\end{array}$ & $\begin{array}{c}401 \cdot 9 \\
31 \cdot 7 \\
10 \cdot 3 \\
12\end{array}$ & $\begin{array}{r}240 \cdot 3 \\
8 \cdot 6 \\
3 \cdot 2 \\
12\end{array}$ \\
\hline
\end{tabular}

Conversion factor from Traditional to SI Units: Thyroxine: $1 \mu \mathrm{g} / 100 \mathrm{ml} \approx 78.8 \mathrm{mmol} / \mathrm{l}$.

Abbreviations as for Table 1 . 
TABLE 3 Main electrocardiographic data and results of His bundle studies during sinus rhythm and right atrial pacing in 6 patients with hypothyroidism

\begin{tabular}{|c|c|c|c|c|c|c|c|c|c|c|c|c|}
\hline \multirow{3}{*}{$\begin{array}{l}\text { Case } \\
\text { No. } \\
\text { (Table 1 }\end{array}$} & \multirow[t]{3}{*}{$H R$} & \multirow{3}{*}{$\begin{array}{l}\text { ECG } \\
\text { data }\end{array}$} & \multicolumn{10}{|c|}{ His bundle electrogram } \\
\hline & & & Interval & $S R$ & Paced & cycle & & & & & & \\
\hline & & & & & 700 & 650 & 600 & 540 & 500 & 400 & 375 & \\
\hline \multirow{4}{*}{1} & \multirow{3}{*}{65} & Low voltage & & & & & & & & & & \\
\hline & & RBBB & AH & 90 & 110 & 145 & 160 & 170 & 180 & 210 & 220 & \\
\hline & & $P R=170 \mathrm{~ms}$ & HV & 60 & 60 & 60 & 60 & 60 & 60 & 60 & 60 & \\
\hline & \multirow{2}{*}{68} & & $\mathrm{AH}$ & 90 & 110 & 135 & 145 & 160 & 170 & 175 & 180 & \\
\hline 2 & & $P R=150 \mathrm{~ms}$ & HV & 40 & 40 & 40 & 40 & 40 & 40 & 40 & 40 & \\
\hline \multirow[t]{2}{*}{6} & \multirow[t]{2}{*}{58} & LAH & $\mathrm{AH}$ & 80 & 80 & 100 & 170 & 200 & 230 & 240 & - & AV block Wenck, $3 / 1$ \\
\hline & & $P R=180 \mathrm{~ms}$ & HV & 70 & 70 & 70 & 70 & 70 & 70 & 70 & - & \\
\hline \multirow{2}{*}{8} & \multirow{2}{*}{59} & ST & AH & 60 & 60 & 70 & 80 & 80 & 90 & 100 & 120 & \\
\hline & & $P R=130 \mathrm{~ms}$ & HV & 55 & 55 & 55 & 55 & 55 & 55 & 55 & 55 & \\
\hline \multirow{2}{*}{9} & \multirow{2}{*}{63} & Low voltage & AH & 100 & 130 & 180 & 230 & 280 & - & - & - & AV block Wenck. $4 / 1$ \\
\hline & & $P R=175 \mathrm{~ms}$ & HV & 50 & 50 & 50 & 50 & 50 & 一 & - & - & \\
\hline \multirow{2}{*}{11} & \multirow{2}{*}{66} & $\int \mathrm{ST}$ & AH & 150 & 180 & 210 & 220 & 250 & - & - & - & AV block Wenck, 3/1 \\
\hline & & $\{\mathrm{PR}=220 \mathrm{~ms}$ & HV & 50 & 50 & 50 & 50 & 50 & 一 & 一 & - & \\
\hline
\end{tabular}

AV block Wenck. $3 / 1$ or $4 / 1$ : second degree AV block with Wenckebach periods $3 / 1$ or $4 / 1$; LAH, left anterior hemiblock; RBBB, right bundle-branch block; ST, non-specific ST changes.

after treatment with thyroid hormone. Atrial refractoriness was not studied on that occasion. In the present study an entirely new group of patients was investigated. It was assumed that in agreement with the experimental data (Freedberg et al., 1970) a prolonged action potential and refractoriness of the atrial muscle might explain the low frequency of atrial arrhythmias during hypothyroidism. Experimental data (Johnson et al., 1973) have shown that the increase in the stimulation rate of the atria in euthyroid and hypothyroid rabbits is associated with a decrease in the 50 per cent repolarization time which was inversely related to the stimulation frequency. The atria from thyrotoxic animals tended to develop arrhythmias if stimulated more than 30 per cent above their intrinsic rates.

In our study a significant prolongation of right atrial MAP and of AERP was found during the hypothyroid state. These findings are in agreement with experimental studies showing a prolonged action potential and refractoriness in hypothyroid atrial myocardium (Freedberg et al., 1970; Arnsdorf and Childers, 1970; Johnson et al., 1973). Though MAP duration and AERP were not identical, and strong correlations between these two parameters could not be shown in normal subjects (Gavrilescu et al., 1972a, b; Brorson, 1975), a change in the same sense was noted in relation to the thyroid status. The differences between MAP duration and AERP can be the result of the differences of the recording site, nonuniform response, or other factors that may separately influence the duration of the action potential and refractoriness (Hoffman, Kao, and Suckling, 1957). We have selected cases without any obvious cardiac disease for study in order to appreciate the effects of hypothyroidism on the electrophysiological properties of the atrial muscle. The lengthening of MAP duration may be related to the ionic basis of repolarization and the direct influence of thyroid hormone on membrane conductance (Johnson et al., 1973). An increase of the amplitude and overshoot of the action potentials from hypothyroid atrial fibres was found (Johnson et al., 1973). We have not observed any evident change of MAP amplitude associated with the thyroid status; however, this parameter has limited value in MAP analysis (Olsson, 1971).

Changes in right atrial MAP duration in man have been described under the influence of antiarrhythmic drugs (Olsson, Brorson, and Varnauskas, 1973; Olsson, 1974) or in association with the tendency of atrial fibrillation to recur after successful conversion (Olsson, Cotoi, and Varnauskas, 1971; Cotoi et al., 1972b). We believe that in interpreting right atrial MAP in normal and pathological conditions, the thyroid state must be taken into consideration.

The effects of thyroid state on AV conduction are also a matter of interest. The occurrence of atrial tachyarrhythmias with a rapid ventricular rate, which respond poorly to digitalis is a common feature of hyperthyroidism. Electrophysiological studies (Goel, Hanson, and Han, 1972) have shown a shortening of the AV conduction time and of the functional refractory period of the AV conduction system in hyperthyroid dogs while opposite changes were noted in hypothyroid animals. Experimental studies (El-Shahaway, 1974) with 
the aid of His bundle recordings have shown enhanced intracardiac conduction after thyroid hormone administration. AV conduction delay and intraventricular conduction defects have been reported in hypothyroid patients (Ibrahim, 1957) but there have been no electrophysiological studies of AV conduction in clinical hypothyrodism.

Our data show that in 2 of the 6 patients there was a latent conduction defect at the AV level, while another showed first degree AV block in sinus rhythm. InfraHisian conduction delay was encountered in 2 patients. One of them had right bundle-branch block and the other one had left anterior hemiblock. These findings suggest generalized impairment of conduction in the specialized His-Purkinje system in both patients. Their RP intervals on the surface electrocardiogram were within normal limits though the patient with left anterior hemiblock also had latent AV conduction disturbance, developing induced supraHisian block at a relatively low heart rate ( 120 beats per minute). It appears from our study that the AV conduction system may sometimes present a latent or manifest conduction defect in middle-aged patients with hypothyrodism and without clinical cardiac disease. The limited number of cases studied, and the lack of more analytical studies which might exclude other latent cardiac disease (coronary angiography, myocardial biopsy), make it difficult to generalize from these observations.

\section{References}

Arnsdorf, M. F., and Childers, R. W. (1970). Atrial electrophysiology in experimental hyperthyroidism in rabbits. Circulation Research, 26, 575.

Bellet, S. (1971). Clinical Disorders of the Heart Beat, 3rd ed. Lea and Febiger, Philadelphia.

Brorson, L. (1975). Electrophysiological Properties of Right Atrium. Gotabkünlav, Göteborg.

Cotoi, S., Constantinescu, L., and Gavrilescu, S. (1972a). The effect of thyroid state on monophasic action potential in human heart. Experientia, 29, 797.

Cotoi, S., Gavrilescu, S., Pop, T., and Vicas, E. (1972b). The prognostic value of right atrium MAP after conversion of atrial fibrillation. European fournal of Clinical Investigation, 2, 472.

El Shahaway, M. (1974). The effect of acute thyroid hormone administration in intracardiac conduction. Circulation, 49, Suppl. III, 171.
Freedberg, A. S., Papp, J. G., and Vaughan Williams, E. M. (1970). The effect of altered thyroid state on atrial intracellular potentials. Fournal of Physiology, 207, 357.

Gavrillescu, S., Cotoi, S., and Pop, T. (1972a). The monophasic action potential of the right atrium. Cardiology, 57, 200.

Gavrilescu, S., Cotoi, S., Pop, T., and Luca, C. (1972b). The monophasic action potential of the right atrium. In Actas del VI Congreso Europeo de Cardiologia, p. 221. Ed. Pax Montalvo, Madrid.

Goel, B. G., Hanson, C. S., and Han, J. (1972). AV conduction in hyper and hypothyroid dogs. American Heart fournal, 83, 504.

Hoffman, B. F., Cranefield, P. F., Lepeschkin, E., Surawicz, B., and Herrlich, H. C. (1959). Comparison of cardiac monophasic action potentials recorded by intracellular and suction electrodes. American fournal of Physiology, 196, 1297.

Hoffman, B. F., Kao, C. Y., and Suckling, E. E. (1957). Refractoriness in cardiac muscle. American fournal of Physiology, 190, 473.

Ibrahim, M. (1957). Myxedema heart. Fournal-Lancet, $2,114$.

Johnson, P. N., Freedberg, A. S., and Marshall, J. M. (1973). Action of thyroid hormone on the transmembrane potentials from sinoatrial node cells and atrial muscle cells in isolated atria of rabbits. Cardiology, 58, 273.

Olsson, S. B. (1971). Monophasic Action Potentials of Right Heart. Elanders Bokryckeri Aktienbolog, Göteborg.

Olsson, S. B. (1974). Atrial repolarization in man. Effect of beta receptor blockade. British Heart fournal, 36, 806.

Olsson, S. B., Brorson, L., and Varnauskas, E. (1973). Class 3 antiarrhythmic action in man. Observations from monophasic action potential recordings and amidodarone treatment. British Heart fournal, 35, 1255.

Olsson, S. B., Cotoi, S., and Varnauskas, E. (1971). Monophasic action potential and sinus rhythm stability after conversion of atrial fibrillation. Acta Medica Scandinavica, 190,381 .

Scherlag, B. J., Lau, S. H., Helfant, R. H., Berkowitz, W. D., Stein, E., and Damato, A. N. (1969). Catheter technique for recording His bundle activity in man. Circulation, 39, 13.

Seligson, H., and Seligson, D. (1972). Measurement of thyroxine by competitive protein binding. Clinica Chimica Acta, 38, 199.

Vaughan Williams, E. M. (1970). Classification of antiarrhythmic drugs. In Cardiac Arrhythmias, p. 449. Ed. by E. Sandøe, E. Flensted-Jensen, and K. Olesen. AB Astra Södertälje, Sweden.

Wit, A. L., Weiss, M. B., Berkowitz, W. D., and Rosen, K. M. (1970). Patterns of atrioventricular conduction in the human heart. Circulation Research, 27, 345.

Requests for reprints to Professor S. Gavrilescu, Spitalul Judetean, Clinica I Medicala, Bul. St. Plavat Nr. 156, 1900 Timisoara, Rumania. 